\title{
Policy Communication of Licensing Business Swallow's Nests in Pekanbaru City
}

Rinaldy May Wendra ${ }^{1}$, Endang Larasati ${ }^{2}$, Tri Yuniningsih ${ }^{3}$, Teuku Afrizal ${ }^{4}$

Student of Master of Public Administration, Faculty of Social and Political Sciences Diponegoro University ${ }^{1}$ Lecturers of Public Administration, Faculty of Social and Political Sciences, Diponegoro University 2,3,4

Email: rinaldym75@gmail.com

(Received: May 17-2020; revised: Juny 10-2020; published: December 31-2020)

\begin{abstract}
Communication in the policy implementation process is intended so that all stakeholders involved can understand and show attitudes and provide responses to the policy implementation process. Poor communication between the stakeholders involved will only create ineffectiveness in the policy implementation process. This study aims to analyze the communication in the policy of managing and exploiting swallow's nests in Pekanbaru. This research is a qualitative descriptive study, with data collection techniques using interviews, documentation and observation. Communication on the implementation of the business permit policy for managing and exploiting swallow's nest in Pekanbaru City is seen from the process of delivering information to policy implementers and target groups, as well as being analyzed from the aspects of the communication media used and the accuracy and clarity of the information received. The delivery of information about policies to policy implementers is quite good, but communication to the sasarang group is not optimal with communication media in the form of socialization that is not yet effective.
\end{abstract}

Keywords: communication, policy implementer, target group, communication media

\section{INTRODUCTION}

One of Indonesia's natural resources that has a high selling value is swallow's nest. Sumatra, Kalimantan and Java are some of the areas that have white swallow's nest products with great quality and quantity. Almost all of the swallow nests produced become an export commodity, especially for the destinations of Singapore, Hong Kong, Taiwan, Korea and Japan (Susilowati, 2018). China is the country with the largest consumption of swallow's nest in the world. In the first semester of 2019, China imported 557 tons of swallow's nest or around USD 115 million and 60 percent of it was imported from Indonesia (https://www.kemendag.go.id/id/newsroom/press-release/taiki-ekspor-kemendag-eliminateillegal-trade-bird's nest-swallow-1).

Cultivation of swallow's nest is basically beneficial for the community, region and country. However, from an environmental aspect, cultivating swallow's nest outside of their natural habitat has the risk of creating new problems for the surrounding environment. Swallow's nest can cause 24 types of diseases to humans if the cultivation location is not in accordance with the rules and does not pay attention to environmental quality. Researcher from the Indonesian Institute of Sciences (LIPI), Mas Nurjito, stated that the spread of disease carried by swallows can be through saliva, breath and droppings (http://lipi.go.id/berita/24-penyakit- because-birdswallow / 2732). Vaiappuri (2017) mentions several issues faced by swallow nest entrepreneurs in Malaysia, including noise pollution, threats to the cultural tourism industry in George Town, 


\author{
332 | Jurnal Ilmiah Ilmu Administrasi Publik: Jurnal Pemikiran dan Penelitian Administrasi \\ Publik \\ Volume 10 Number 2, July-December 2020. Page 331-342
}

the potential for fires from electrical equipment used, inadequate waste disposal management which causes unpleasant odors and water pollution, disrupted public health, and property values around the swallow's nest building have decreased.

Pekanbaru City as one of the areas with a large number of swallow nest management businesses, has issued a policy regarding swallow nest business through Pekanbaru City Regional Regulation Number 3 of 2007 concerning Business Permits for Management and Exploitation of Swallow's Nests in Pekanbaru City. However, data from the Pekanbaru City Investment and One Stop Integrated Services Service (DPMPTSP) show that most swallow nest businesses in Pekanbaru City do not have permits. There is even one district where not a single swallow nest business has a permit. Of course this is very sad because if you see in the field there are so many swallow nest businesses in Pekanbaru City, even the location is close to community settlements. According to the Pekanbaru City Investment and One-Stop Integrated Service (DPMPTSP) Office in 2019, to date, there are around 59 licensed swallow bird nests. Although the regulations governing swallow nest cultivation have been issued by the Pekanbaru City Government, currently the swallow nest cultivation business in Pekanbaru City is very unsettling for residents, especially if it is located in the middle of Pekanbaru City and close to residential areas. The loud sound of the swallow tapes can be heard reaching the community, so it is very disturbing, especially with the risk of environmental pollution which results in the emergence of several diseases that can interfere with human health (https://riaupos.jawapos.com/pekanbaru/19/01/2014/41407/pekan-depan-dprd-pjual-timterpadu-sarang-walet.html).

Seeing that the number of swallow nest business permits in Pekanbaru is still low, it indicates that there are obstacles in the policy communication process. The goals and objectives of policies that have been made by the government must be able to be transmitted to the target group and all stakeholders so that they can reduce distortions (Edward in Kuncoro, 2019). The purpose and objectives of a policy that is unclear or even unknown target group, then it is likely that will happen is the emergence of resistance of the target group or all the stakeholders involved in the process of policy implementation.

Thomas R. Dye in Nugroho 2018 defines public policy as everything that is done and not done by the government, why they do it, and the results that make life together appear different. Hoogerwerf (in Sjoraida, 2015) states that policies have action programs, target groups and implementing elements. Policies that are formulated on the basis of the right public problems and the existence of guarantees to carry out the solutions in the field will result in the effectiveness of implementing a policy (Dunn in Sulastiyo et al, 2016). The implementation of a policy requires an appropriate policy formulation process so that targets are achieved, and also requires policy evaluation to correct deficiencies and obtain input as a consideration for new policy making in the future (Isril, 2013). According to Edward in Kuncoro (2019) communication in the policy implementation process is intended so that all stakeholders involved can understand and show attitudes and provide responses to the policy implementation process. Poor communication between the stakeholders involved will only create ineffectiveness in the policy implementation process (Nugroho in Kuncoro, 2019). The benefits of 
implementing good communication in the policy implementation process will also be able to provide information and know the consequences that will occur now and in the future, so that every stakeholder involved can determine alternative steps or plans that can be used during the policy implementation process.

Rahmadona's research (2017) concludes that a dialogical communication process with a bottom up approach can encourage the successful implementation of policies to increase the competitiveness of shallots in Majalengka Regency by involving all stakeholders in defining the problems faced to reach consensus in the form of solutions through a two-way communication process. Kuncoro's research (2019) concludes that the success in the process of implementing disaster mitigation policies in the southern coastal area is influenced by the communication used by the Bantul district government. Communication used in the process of implementing disaster mitigation policies in coastal areas is direct communication and indirect communication. Of the two types of communication used, direct communication is the most effective form of communication to use. The descriptions of some of the above studies can show that proper communication is needed in the process of implementing policies, especially policies regulating the exploitation of swallow nests. Therefore, this study will analyze the communication in the policy of managing and exploiting swallow's nest business permits in Pekanbaru.

\section{METHOD}

The approach method used is a qualitative research method with a descriptive approach. The focus of this research is the implementation process of a business permit policy for managing and exploiting swallow's nest in Pekanbaru City. Research on the implementation process of a business permit for managing and exploiting swallow's nest was conducted in Pekanbaru City. In this study, the phenomenon to be studied is the communication in the policy of managing and exploiting swallow's nest business in Pekanbaru City, which consists of the media used for communication and the accuracy and clarity of the information received .

The data that the author uses in this study are primary data (from informants) and secondary data (journals, books and other supporting documents). In determining informants using a purposive technique, and there were 12 informants from the Pekanbaru City Investment and One Stop Services Agency, Pekanbaru City Regional Development Planning Agency, Pekanbaru City Civil Service Police Unit, Pekanbaru City Health Service, Pekanbaru City Agriculture and Fishery Service Agency, Regional Revenue of Pekanbaru City, Department of Environment and Sanitation of Pekanbaru City, Office of Industry and Trade of Pekanbaru City, Office of Public Works and Spatial Planning of Pekanbaru City. Collecting data using interviews, documentation and observation. This study uses an interactive data analysis model with the following steps: data reduction, data presentation and conclusion drawing. The validity of the data used in this study was to use source triangulation techniques. 


\author{
334 | Jurnal Ilmiah Ilmu Administrasi Publik: Jurnal Pemikiran dan Penelitian Administrasi \\ Publik \\ Volume 1o Number 2, July-December 2020. Page 331-342
}

\title{
RESULT AND DISCUSSION
}

The policy for managing and exploiting swallow's nests in Pekanbaru City is regulated in Pekanbaru City Regional Regulation Number 3 of 2007 concerning Business Permits for Management and Exploitation of Swallow's Nests. The regional regulation states that the permit application is accepted and recorded administratively by the Animal Husbandry Service, to then carry out a coordinative on-site research and discussion by the Assessment Team. The Assessment Team consists of the City Planning Office, City Health Service, Regional Revenue Service, Bapedalda, Animal Husbandry Service, City Government Economic Section, as well as Services, Agencies, Offices and other related sections. The regional regulation is supported by technical regulations in the form of Pekanbaru Mayor Regulation Number 2 of 2009 concerning Implementation Guidelines and Technical Guidelines of Regional Regulation Number 3 of 2007 concerning Business Permits for Management and Exploitation of Swallow's Nests and Regional Regulation Number 7 of 2007 concerning Retribution for Management and Exploitation of Bird's Nests. Swallow.

The authority of the business permit for managing and exploiting swallow nests in Pekanbaru City is given to the Pekanbaru City Investment and One Stop Services (DPMPTSP) based on Pekanbaru Mayor Regulation Number 260 of 2017 concerning Position, Organizational Structure, Duties and Functions as well as Work Procedures for the Investment Service and Pekanbaru City One Stop Services and Pekanbaru Mayor Regulation Number 15 Year 2019 Regarding Delegation of Licensing and Non-licensing Authorities to the Head of the One Stop Investment and Integrated Services Service. The implementation of the business permit policy for managing and exploiting swallow's nest in Pekanbaru City is analyzed through aspects of communication, resources, disposition and bureaucratic structure.

Policy implementers must know what must be done in order for policy implementation to be successful. Submission of the aims, objectives and content of policies to policy implementers will affect the level of knowledge of policy implementers regarding policies that must be implemented. Information on policy objectives and targets must also be conveyed to target groups to reduce distortions in implementation. If the delivery of the goals and objectives of a policy are not clear or even not known at all by the target group, then it is likely there will be resistance from the target group. In this case the transformation of information regarding all matters relating to policy is contained in the policy implementation communication system. Communication regarding policy goals and objectives is made to policy implementers and target groups. In this case, communication of policy implementation is seen through the media (transmission) used in policy implementation, consistency of policy implementation communication and clarity of information among policy implementers.

Communication in implementing the business permit policy for managing and exploiting swallow's nests in Pekanbaru City is carried out to policy implementers and target groups. At the beginning of the issuance of the policy, administrative authority rests with the Livestock Service Office of Pekanbaru City. Submission of policy objectives and targets for the 
management and exploitation of swallow's nest policies to policy implementers is carried out through coordination meetings with related agencies. In this activity, it was conveyed that this policy has the aim of preserving the environment in managing and exploiting swallow's nest with an environmental perspective. Requirements for permit application and assessment techniques are conveyed in particular to service officers and the Assessment Team.

The existence of swallow nest business in Pekanbaru existed even before this policy was enacted. However, due to many negative impacts on the surrounding community, the government is trying to curb the swallow nest business by enacting Regional Regulation No. 3 of 2007. This regulation was made with the aim of preserving the environment in managing and exploiting swallow's nest with an environmental perspective. This means that all swallow nest businesses in Pekanbaru must comply with the existing regulations in the Perda, even for swallow nest businesses that existed before the regulation was enacted. This is stated in Perda No. 3 of 2007 in Chapter II Article 2 paragraph (1) which states that "The objects of business permits for swallow nest management and exploitation are all business locations in the city area whose activities are intended to manage and cultivate swallow nests", Article 3 which reads "The subject of a swallow's nest management business license is any person or legal entity whose activities are managing and operating a swallow's nest", as well as article 6 paragraph (1) which states "Every person or entity that manages and manages a swallow's nest must has a permit from the Mayor ". From the excerpt from the article in the intended policy, it can be seen that this rule is applied to all swallow nest businesses in Pekanbaru without exception. This is because the initial goal of the government to implement this policy is to curb swallow nest business so that environmental quality impacts are maintained, community comfort can be guaranteed, and the quality of swallow's nest products is in accordance with hygiene standards so that it has great opportunities for the export market.

The implementation of a business permit policy for managing and exploiting swallow's nest in Pekanbaru City can be carried out effectively if the size and objectives of the policy are understood by the individual who is responsible for achieving the policy, the accuracy of communication with the implementers, and consistency or uniformity of the basic measures and objectives communicated with various sources of information. In this case the communication referred to is not only vertically from top to bottom in the form of orders, instructions, warnings but also from the bottom up in the form of suggestions, suggestions, opinions and reports. Apart from vertical communication, which is no less important is horizontal communication, namely coordination with other units involved in achieving policy objectives. With intense communication with policy implementers, the executors of the business permit for managing and exploiting swallow's nest in Pekanbaru City can receive information clearly and consistently so that policy implementers can know what can be expected of them and know what they should do.

When the transfer of authority from the Pekanbaru City Animal Husbandry Office to the Pekanbaru City Investment and One Stop Services Service (DPMPTSP), socialization was carried out again to structural officials, service officers and staff in charge of the said policy duties. However, the procedure for assessing the feasibility of a business permit for managing and exploiting swallow's nest is still in a technical team consisting of several related technical agencies. With the large number of licensing and non-licensing authorities moving to 


\author{
336 || Jurnal Ilmiah Ilmu Administrasi Publik: Jurnal Pemikiran dan Penelitian Administrasi \\ Publik \\ Volume 1o Number 2, July-December 2020. Page 331-342
}

DPMPTSP Pekanbaru City, this demands the readiness of human resources, optimal quality of learning and effectiveness of socialization so that the human resources in Pekanbaru City DPMPTSP have a good understanding and can provide the best service for the procedures for managing permit and nest exploitation. swallow.

Knowledge of policy implementers will influence decisions and actions in their implementation. In the policy of managing and exploiting swallow's nests in Pekanbaru City, policy implementers gain knowledge in accordance with their main duties and functions. This knowledge is obtained from a hierarchical command structure corresponding groove organization as well as in the meeting of coordination as mentioned above. Communication made to policy implementers includes policy content in the form of benefits to be generated, interests affected by the policy, and the degree of change desired. Other matters conveyed in the communication referred to were the requirements and methods of obtaining a permit, the validity period of the permit, supervision and criminal provisions.

The benefits that will be generated from this policy are reflected in the policy objectives listed in the dictum Considering letter b, which reads, "that in order to preserve the environment in managing and exploiting swallow nests with an environmental perspective, it is deemed necessary to regulate licensing procedures for managing and exploiting swallow's nests. . " The interests that are affected by the business permit policy for managing and exploiting swallow's nests in Pekanbaru are all objects and subjects of this policy which are listed in Chapter II article 2 paragraph (1) and read, "The objects of business permits for managing and exploiting swallow's nests are all business locations. in a city area whose activities are intended to manage and cultivate swallow's nest ", as well as article 3 which reads," The subject of a swallow nest management business license is any person or legal entity whose activities are to manage and cultivate swallow's nest. " The degree of change desired in the policy for swallow nest management and exploitation business permits in Pekanbaru is stated in the policy targets, namely ownership of business permits for all swallow nest management and exploitation activities, increased contribution of swallow nest business levies to Regional Original Income (PAD), increased product quality of swallow's nest business, improving the quality of the swallow's nest business environment.

The obligation to have a business license for all swallow nest businesses in Pekanbaru is stated in Chapter IV article 6 paragraph (1) which reads, "Every person or entity that manages and operates swallow's nest must have a permit from the Mayor." Requirements for the issuance of a swallow's nest business permit are the most important things conveyed in communication with policy implementers, because policy implementers will directly provide public services to target groups. The requirements for the issuance of a permit are listed in Chapter IV article 6 paragraph (2). The application for a swallow's nest business license is registered at the Animal Husbandry Service based on Article 7 paragraph (1) of the Pekanbaru City Regional Regulation Number 3 of 2007, but now this authority has transferred to the Pekanbaru City Investment and One-Stop Integrated Service Service based on Pekanbaru Mayor Regulation Number 15 of 2019 concerning Delegation of Licensing and Non-licensing Authorities to the Head of the Investment and One Stop Integrated Services Service. The review of the location of the 
swallow's nest business is carried out in a coordinative manner with the technical team that is the location appraisal team for the issuance of a business license, which then results from the research and field survey being a recommendation for a swallow's nest business to be eligible for a business license or not, as stated in article 7 paragraph (2) Pekanbaru City Regional Regulation Number 3 of 2007.

A business permit for managing and exploiting swallow's nest that has been issued has a validity period of 5 years and can be extended again with the approval of the Mayor in accordance with Chapter VI article 9 paragraph (1) of Pekanbaru City Regulation Number 3 of 2007. Furthermore, for the provision of guidance, supervision and control as stated in Chapter $\mathrm{X}$, article 17 and article 18, it is stated that the guidance, supervision and control of swallow nest management and exploitation permits is carried out by an agency determined by the mayor. Sanctions for swallow nest businesses that violate this policy are listed in Chapter XII article 20 paragraph (1) which states that imprisonment for a maximum of 3 (three) months or a fine of up to Rp. 50,000,000, - (fifty million rupiah).

The accuracy and clarity of information received by policy implementers is reflected in the policy implementer's understanding of the policy content. Implementing policies here consist of structural officers and DPMPTSP staff and the Technical Team. The policy implementers' understanding of the content of the policy is quite good, this is reflected in the results of interviews from the Head of Licensing and Non-Licensing Services A DPMPTSP Pekanbaru City, Head of the Licensing and Non-Licensing Services Section A / I, along with 5 staff in charge of managing business permit services. and exploitation of swallow's nest in Pekanbaru city. From the results of interviews regarding policy objectives, policy objectives, policy objects, policy subjects, business permit requirements, business permit application flow, business license validity period, supervision, and criminal sanctions against structural officials and staff of Pekanbaru City DPMPTSP and the Technical Team in charge of permit matters The results showed that all informants were able to explain well the contents of the policy for swallow nest management and exploitation business permits along with other technical matters not listed in the policy. Other technical matters referred to, for example, one of the requirements for a swallow's nest management and exploitation business permit is an IMB, but if an entrepreneur who will apply for a business permit for managing and exploiting a swallow's nest does not have an IMB, the entrepreneur can immediately register an application for a business permit for nest management and exploitation. swallow with the stated requirements along with the requirements for issuing IMB. So, the registration process is carried out in one process only, so you do not have to visit the Public Service Mall repeatedly.

The delivery of policies to target groups is carried out through outreach activities. The socialization activities were carried out by presenting related agencies and representatives of swallow nest entrepreneurs in Pekanbaru. Furthermore, the socialization activities were carried out directly by visiting the swallow's nest business. However, the socialization activities carried out have not provided optimal results, because the socialization carried out by door to door has a major obstacle, namely the difficulty of meeting the owner of a swallow's nest business. The existence of the swallow's nest business building which is quite closed makes it difficult for policy implementers because it is often found that business owners are not in the place of business or even find it difficult to enter the area of the swallow's nest business. The reluctance 


\author{
338 || Jurnal Ilmiah Ilmu Administrasi Publik: Jurnal Pemikiran dan Penelitian Administrasi \\ Publik \\ Volume 10 Number 2, July-December 2020. Page 331-342
}

of swallow's nest entrepreneurs to apply for business permits is also suspected of being reluctant to pay retribution on the grounds that their business has not yet generated income through harvesting swallow's nest.

However, from the business side, it was found that the communication made by the government to the swallow's nest entrepreneurs was not optimal. The swallow's nest entrepreneur is of the opinion that the requirements needed to obtain the said business license are quite convoluted. The swallow's nest entrepreneur also informed that the obstacles in communication with related agencies were due to their presence outside the city more often . Swallow nest entrepreneurs said that the business location for swallow nest businesses had been built before the issuance of the regional regulation that regulates this, making it difficult for them to meet the requirements regarding the minimum distance between business locations and community settlements.

Information from DPMPTSP Pekanbaru City shows that there were around 108 applications for permits for swallow nest management and exploitation in 2019 that were rejected by Pekanbaru City DPMPTSP. The rejection is caused by the location of the swallow's nest business that does not meet the requirements stated in the policy. Issues regarding the minimum distance from residents' settlements and environmental quality are still the main causes of rejection of applications for swallow nest business permits. Not optimal communication between policy implementers and target groups has an impact on the target group's lack of understanding and knowledge regarding policy content. The locations where the permit application was rejected are scattered in all sub-districts of Pekanbaru City.

DPMPTSP Pekanbaru City uses the website, Facebook, Instagram, YouTube and other social media to socialize licensing and non-licensing procedures. The procedures, requirements and Standard Operating Procedure (SOP) regarding the business permit for managing and exploiting swallow's nest can be easily accessed on the DPMPTSP Pekanbaru City website, and of course makes it easier for entrepreneurs who will take care of this permit. Requirements for obtaining a business permit for the management and exploitation of swallow's nest based on Pekanbaru City Regulation Number 3 of 2007 are:

1. Application letter

2. Copy of KTP / NIB,

3. Copy of KK

4. Photocopy of PBB Settlement

5. Copy of NPWPD

6. Photocopy of Deed of Establishment for companies with legal status

7. Photocopy of brief description of the activity work plan

8. Environmental statement letter not objection

9. Location map

10. Photos of business premises 
11. A statement letter that will employ local workers

12. Statement letter obeying and obeying regulations

13. Letter from the Head of the Village regarding the existence of the business

14. Copy of IMB

15. Photo size 4 x 6 (2 sheets)

The website of DPMPTSP Kota Pekanbaru also provides information on the processing of business permits for managing and exploiting swallow's nests which are free of charge. However, in other social media, the procedures, requirements and SOPs regarding the business permit for managing and exploiting swallow's nest are not explained in detail, so they are not effective as a medium of socialization. The obstruction in the delivery and dissemination of information to policy target groups has a direct effect on the clarity and consistency of good information for swallow nest entrepreneurs. Information on policies received by the target group is not comprehensive, so the majority of swallow nest entrepreneurs do not have a good understanding of their obligations to obtain business permits and pay fees.

From the explanation above, it can be seen that the process of communicating policy objectives to policy implementers through meetings has been running effectively, because policy implementers have a good understanding of policy goals and objectives. However, the communication process to the target group is still not optimal so that the information obtained is unclear which causes reluctance to take care of permits for swallow's nest business.

Communication is a process for conveying information from information givers or communicators to information recipients or communicants, while the communication referred to in this study is policy communication which is a process for conveying policy information from policy makers to policy implementers and target groups (Sholiq in Ramadani, 2019). This is what places communication as an important aspect in the implementation of a business permit policy for managing and exploiting swallow's nest in Pekanbaru City, if policy makers do not communicate well and clearly with policy implementers, policy implementation is not in accordance with the intentions outlined in the policy. Communication on the implementation of the business permit policy for managing and exploiting swallow's nest in Pekanbaru City is seen from the process of delivering information to policy implementers and target groups, as well as being analyzed from the aspects of the communication media used and the accuracy and clarity of the information received.

Submission of policy objectives and targets for the management and exploitation of swallow's nest policies to policy implementers is carried out through coordination meetings with related agencies. Communication is also done vertically and horizontally. With sufficiently intense communication to policy implementers, executors of business permit policies for managing and exploiting swallow bird nests in Pekanbaru City can receive information clearly and consistently so that implementers can gain knowledge and understanding of things that become implementation standards and things that must be done by implementers.

This is in accordance with what Edward III stated in Agustino (2006) regarding the implementation of policies which require those who are responsible for implementing policies to know what to do in order to implement policies effectively. The delivery of orders for the implementation of a policy must be done clearly, accurately, and consistently to the parties 


\author{
340 | Jurnal Ilmiah Ilmu Administrasi Publik: Jurnal Pemikiran dan Penelitian Administrasi \\ Publik \\ Volume 10 Number 2, July-December 2020. Page 331-342
}

implementing the policy. The appointed policy implementer is at risk of misunderstanding when the implementation of the policies expected by the policymaker seems unclear to be specified. If there is confusion and uncertainty on the part of the policy implementer regarding what must be done for the policy implementation process, it opens up opportunities for the reluctance of policy implementers to implement policies as desired by policy makers.

The delivery of policies to target groups is carried out through outreach activities. The socialization activities were carried out by presenting related agencies and representatives of swallow nest entrepreneurs in Pekanbaru. Furthermore, the socialization activity was carried out directly by visiting the swallow's nest business. However, the socialization activities carried out have not provided optimal results, because the socialization carried out by door to door has a major obstacle, namely the difficulty of meeting the owner of a swallow's nest business. The obstruction in the delivery and dissemination of information to policy target groups has a direct effect on the clarity and consistency of good information for swallow nest entrepreneurs. McAvoy (2014) concluded that the dissemination of a policy can be facilitated by careful planning, extensive consultation and communication, coupled with comprehensive staff training.

Policy implementers must convey to the target group the aims and objectives of the policy. The success of this communication is supported by the knowledge of policy implementers who must know what to do in policy implementation. Ineffective implementation of policies can originate from the ignorance of the target group regarding the targets and objectives of the policy, causing resistance from the target group (Koine, 2014). As happened in the implementation of a business permit policy for managing and exploiting swallow's nests in Pekanbaru City, where communication from policy implementers to target groups was ineffective which resulted in the lack of licensed swallow nest business. Edward III in Agustino (2006) describes several obstacles in communication transmission, namely:

1. There is a conflict between policy implementers and orders issued by policy makers, which results in direct distortions and obstacles in policy communication.

2. Information that is delivered through a multi-layered hierarchical bureaucracy, which causes distortion of the communication by the long chain of information that could lead to biased information.

3. Perception problems and the inability of policy implementers to understand the requirements of a policy.

The target group will receive a policy depending on the quality of communication made by the implementer of the policy. The quality of communication will ultimately affect the effectiveness of public policy implementation. In other words, delivering policy content through quality communication will support the policy implementation process. Thus, the use of communication media also determines the dissemination of policy content to target groups. This is in line with Agustino's opinion (in Nurwanda, 2017) which states that the success of policy implementation performance is measured from the size and objective of policies that are realistic with the socio-cultural level at the level of policy implementers and target groups. 


\section{CONCLUSION}

Communication on the implementation of the business permit policy for managing and exploiting swallow's nest in Pekanbaru City is seen from the process of delivering information to policy implementers and target groups, as well as being analyzed from the aspects of the communication media used and the accuracy and clarity of the information received. Submission of policy objectives and targets for the management and exploitation of swallow's nest policies to policy implementers is carried out through coordination meetings with related agencies. Communication is also done vertically and horizontally. With sufficiently intense communication to policy implementers, executors of business permit policies for managing and exploiting swallow bird nests in Pekanbaru City can receive information clearly and consistently so that implementers can gain knowledge and understanding of things that become implementation standards and things that must be done by implementers. . The delivery of policies to target groups is carried out through outreach activities. The socialization activities were carried out by presenting related agencies and representatives of swallow nest entrepreneurs in Pekanbaru. Furthermore, the socialization activities were carried out directly by visiting the swallow's nest business. However, the socialization activities carried out have not provided optimal results, because the socialization carried out by door to door has a major obstacle, namely the difficulty of meeting the owner of a swallow's nest business. The obstruction in the delivery and dissemination of information to policy target groups has a direct effect on the clarity and consistency of good information for swallow's nest entrepreneurs. Policy implementers must convey to the target group the aims and objectives of the policy. The success of this communication is supported by the knowledge of policy implementers who must know what to do in policy implementation.

\section{REFERENCES}

Development, JK, Rahmadona, L., \& Fariyanti, A. (2018). Communication of Government Policy on Competitiveness of Shallots Commodities in Majalengka Regency. Journal of KMP (Journal of Development Communication), 15 (2), 37-51. https://doi.org/10.29244/jurnalkmp.15.2.

Kuncoro, D., Islam, U., Muhammad, K., Banjarmasin, AA, \& Policy, I. (2019). COMMUNICATION PROCESS IN THE IMPLEMENTATION OF DISASTER MITIGATION POLICIES. 2 (2).

McAvoy, BR, \& Yallop, JJ (2013). Implementing a smoke-free policy in an inpatient withdrawal unit. Journal of Smoking Cessation, 9 (2), 119-121. https://doi.org/10.1017/jsc.2013.39

Ramadani, T., Pakpahan, F., Adi Pradana, S., Agus Supriyanto, M., \& Mardiyono, E. (2019). Implementation of the One Map Energy and Mineral Resources Policy (Esdm One Map) at 
342 | Jurnal Ilmiah Ilmu Administrasi Publik: Jurnal Pemikiran dan Penelitian Administrasi Publik

Volume 10 Number 2, July-December 2020. Page 331-342

the Ministry of Energy and Mineral Resources of the Republic of Indonesia. Renewal Matrix, 3 (2), 109-118. https://doi.org/10.21787/mp.3.2.2019.109-118

Sjoraida, DF (2015). Implementation of Public Information Disclosure Policy in West Java $\begin{array}{lllll}\text { Provincial } & \text { Government. } & \text { Sociohumaniora, } & 17 & \text { (3), }\end{array}$ https://doi.org/10.24198/sosiohumaniora.v17i3.8338

Sulastiyo, D., Kartodihardjo, H., \& Soedomo, S. (2016). The Effectiveness of Policy Implementation on Forest Rehabilitation and Reclamation. Journal of Tropical Silviculture, 07 (3), 181-187. 